\title{
VENTILATORY COST OF EXERCISE BEFORE AND MITRAL VALVOTOMY
}

\author{
BY
}

\author{
J. P. P. STOCK AND M. C. S. KENNEDY \\ From the Stoke on Trent Hospital Group
}

(RECEIVED FOR PUBLICATION MARCH 21, 1959)

We have previously reported measurements of the maximum ventilatory capacity and the ventilatory requirements for a standard exercise in 26 patients with mitral stenosis (Stock and Kennedy, 1953). A small but variable reduction in maximum ventilatory capacity was noted which appeared to bear little relation to the severity of the patients' symptoms. On the other hand, it was found that increasing disability in mitral stenosis tended to be associated with an increasing ventilatory cost of exercise. We suggested that this increased ventilation might prove useful as an objective index of disability.

In this communication, serial measurements of the ventilatory cost of exercise before and after operation in 85 patients with mitral stenosis treated surgically are presented, together with data from a further 20 patients whose symptoms did not warrant operation. In analysing the data, we have tried to assess the value of simple ventilatory tests as an objective index of disability and as a measure of operative success. In 40 cases the data obtained at cardiac catheterization have been related to the ventilatory findings.

\section{Ventilatory Function Tests}

The ventilatory cost of exercise has been measured using the Hugh-Jones exercise test (Hugh-Jones, 1952). In this test, after resting ventilation has been recorded, the patient steps on and off a platform, the height and rate of stepping being adjusted according to the patient's weight so that all subjects exercise at a work level of $300 \mathrm{~kg} . \mathrm{m} . / \mathrm{min}$. The exercise is continued for five minutes or until the patient is forced to stop. The average ventilation during each minute of exercise is recorded and ventilation is similarly measured throughout the recovery period until it has fallen again to the resting level. Two principal indices are derived from the test, namely, the "exercise ventilation" (E.V.) and the "standardized ventilation" (S.V.). The former (E.V.) is arbitrarily defined as the ventilation during the last minute of exercise. The latter value (S.V.) is obtained by taking the total excess ventilation above the resting level, from the beginning of exercise to the end of the recovery period, dividing it by the number of minutes of exercise and then adding the resting ventilation.

Throughout the investigation we have used a standard work level of $300 \mathrm{~kg} . \mathrm{m} . / \mathrm{min}$. in all cases for the exercise test. In the patients subjected to valvotomy, two or more pre-operative tests were always done and the results from the second test have been taken to allow for any learning effect. In a few of the cases, the patients' symptoms when first seen did not warrant operation, but they later deteriorated clinically and surgery was advised. In many of the less disabled patients further tests at the higher work levels of 350 and occasionally $450 \mathrm{~kg}$. $\mathrm{m}$./min. were done.

Although most workers have used the E.V. as a measure of ventilatory response to exercise, we consider the S.V. to be the more appropriate index for two reasons. First, provided roughly two minutes of exercise is completed, its numerical value is largely unaffected by whether the patient completes the exercise or not. This has obvious advantages in comparing disabled cardiac patients. Secondly, HughJones (1952) showed that, when five minutes of exercise is completed by normal subjects and by patients with pulmonary disease, the E.V. and S.V. are numerically equal. Although we were able to confirm this finding in normal subjects and patients with pulmonary disease we have found this is by no means always true of disabled mitral patients, who often fail to reach a steady ventilatory state (Stock and Kennedy, 1953). In such patients, the total ventilatory cost of exercise can only be appreciated by using an index which takes the recovery period into account.

Maximum ventilatory capacity was also measured in all subjects directly using the maximum voluntary ventilation test (M.V.V.) of Gilson and Hugh-Jones (1949) and indirectly as described by Kennedy (1953). This latter test was carried out both before and immediately after exercise in all cases.

\section{Clinical Material}

The clinical material consisted of 85 consecutive patients with mitral stenosis treated surgically for whom adequate ventilatory data were available. The severity of each patient's symptoms was assessed on clinical grounds before any ventilatory tests were done, using the criteria for clinical grading of Baker, 
TABLE I

SEX DISTRIBUTION IN FIVE GROUPS OF SUBJECTS

\begin{tabular}{c|c|c|c|c|c|c}
\hline & $\begin{array}{c}\text { Normal } \\
\text { Subject }\end{array}$ & $\begin{array}{c}\text { Grade } \\
\text { I }\end{array}$ & $\begin{array}{c}\text { Grade } \\
\text { II }^{*}\end{array}$ & $\begin{array}{c}\text { Grade } \\
\text { III* }^{*}\end{array}$ & $\begin{array}{c}\text { Grade } \\
\text { IV }^{*}\end{array}$ & Total \\
\hline Males .. & 10 & 7 & 5 & 16 & 2 & 40 \\
Females & 10 & 13 & 13 & 41 & 8 & 85 \\
\hline Total & 20 & 20 & 18 & 57 & 10 & 125 \\
\hline
\end{tabular}

* Eighty-five patients treated surgically.

Brock, Campbell, and Wood (1952). Eighteen of the 85 patients were classed as clinical grade II, 57 as clinical grade III, and 10 as clinical grade IV.

For comparison we have included ventilatory data from a further 20 patients with mitral stenosis whose disability was classed as clinical grade I and similar data from 20 normal subjects. It should be emphasized that since mitral valvotomy was advised in grade II patients only under special circumstances, our cases in this group are selected and include only one patient classed as having an early grade II disability. The sex distribution in the five groups of subjects is shown in Table $\mathrm{I}$.

\section{Analysis of Pre-operative Findings}

RELATION OF Ventilatory COST OF EXercise to Clinical Disability.-The columns in Fig. 1

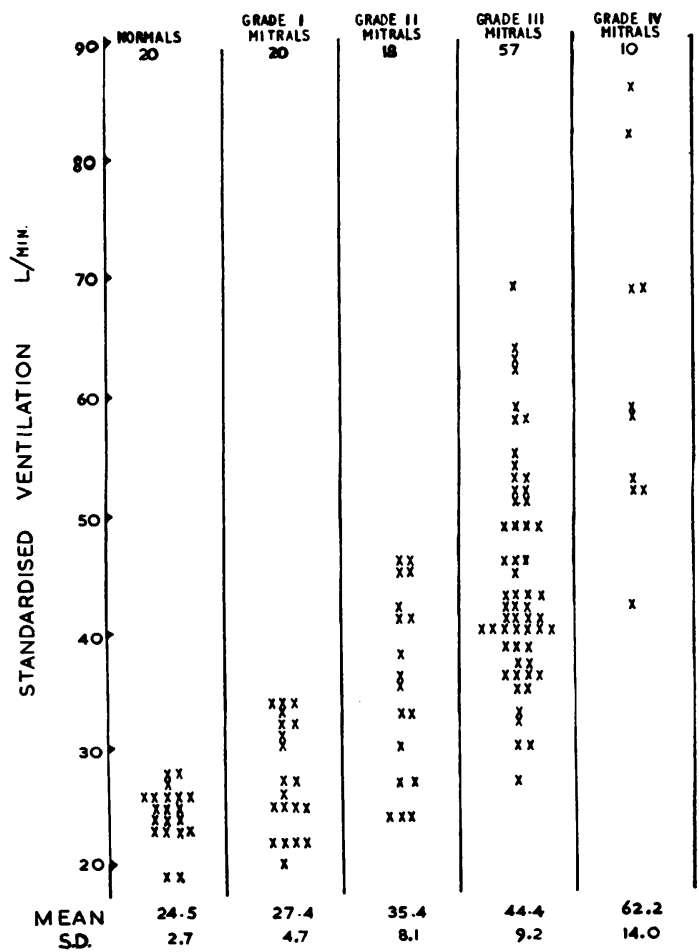

FIG. 1.-Standardized ventilation and clinical grade of 105 patients with mitral stenosis and 20 normal subjects. show the values for the S.V. in 20 normal subjects and in the patients in the different clinical grades of mitral stenosis. The figures confirm our original finding that increasing disability in mitral stenosis tends to be associated with an increasing ventilatory cost of exercise. The mean value of the S.V. for the normal subjects was $24.51 . / \mathrm{min}$. (S.D. 2.7), for grade I patients 27.4 (S.D. 4.7), for grade II 35.4 (S.D. 8.1), for grade III 44.4 (S.D. 9.2), and for grade IV $62.2 \mathrm{l} / \mathrm{min}$. (S.D. 14). Although there is a considerable overlap in the ranges of S.V. in different grades, analysis of variance shows significant between-grade variance; tests of the differences between means based on the error-variance justify the assumption of four separate groups of values of S.V.

Of the 85 patients treated surgically, only six had an S.V. within the normal range, taking $29 \mathrm{1}$./ min. as the upper limit of normal at a work level of $300 \mathrm{~kg} . \mathrm{m} . / \mathrm{min}$. Five of these patients were in clinical grade II and one in clinical grade III. Further details of the six patients with normal S.V. values who underwent surgery are given in Table II. Three of these six patients (Cases 35, 70, and 53) showed an abnormal ventilatory response when the test was repeated at the $350 \mathrm{~kg}$. $\mathrm{m} . / \mathrm{min}$. level, and at operation the valve size of these three patients was estimated to be about $1 \mathrm{~cm} .^{2}$ Of the remaining three patients two showed no increase in ventilation at the $350 \mathrm{~kg}$. $\mathrm{m} . / \mathrm{min}$. work level and one (Case 88 ) an increase of only $29 \%$, which is probably not abnormal. At operation the size of the valves in these three patients was estimated to be $2 \mathrm{~cm} .^{2}$ or more.

TABLE II

CLINICAL DETAILS OF SIX PATIENTS WITH NORMAL S.V. SUBMITTED TO SURGERY

\begin{tabular}{|c|c|c|c|c|c|c|c|}
\hline \multirow[b]{2}{*}{$\begin{array}{l}\text { Clin- } \\
\text { ical } \\
\text { Grade }\end{array}$} & \multirow[b]{2}{*}{$\begin{array}{l}\text { Case } \\
\text { No. }\end{array}$} & \multirow[b]{2}{*}{ Sex } & \multicolumn{2}{|c|}{ S.V. (1./min.) } & \multirow{2}{*}{$\begin{array}{c}\% \\
\text { Increase } \\
\text { in S.V. } \\
\text { at } 350 \\
\text { over } 300 \\
\text { kg. m. } \\
\text { min. }\end{array}$} & \multirow[b]{2}{*}{ Remarks } & \multirow{2}{*}{$\begin{array}{c}\text { Esti- } \\
\text { mated } \\
\text { Valve } \\
\text { Size } \\
\text { at } \\
\text { Operation } \\
\left(\mathrm{cm} .^{2}\right)\end{array}$} \\
\hline & & & $\begin{array}{c}\text { At } \\
300 \\
\text { kg. } \mathrm{m} . \\
\text { min. }\end{array}$ & $\begin{array}{c}\text { At } \\
350 \\
\text { kg. m./ } \\
\text { min. }\end{array}$ & & & \\
\hline \multirow[t]{3}{*}{ I } & 35 & $\mathbf{M}$ & 24 & 42 & 75 & Abnormal res- & 1 \\
\hline & $\begin{array}{l}70 \\
88\end{array}$ & $\underset{\mathbf{M}}{\mathbf{F}}$ & $\begin{array}{l}27 \\
24\end{array}$ & $\begin{array}{l}43 \\
31\end{array}$ & $\begin{array}{l}67 \\
29\end{array}$ & & $\begin{array}{l}1 \\
2\end{array}$ \\
\hline & $\begin{array}{l}51 \\
57\end{array}$ & $\begin{array}{l}\mathbf{F} \\
\mathbf{F}\end{array}$ & $\begin{array}{l}24 \\
27\end{array}$ & $\begin{array}{l}25 \\
26\end{array}$ & $\begin{array}{l}4 \\
0\end{array}$ & $\begin{array}{l}\text { Found at op- } \\
\text { eration not } \\
\text { to have sig- } \\
\text { nificant mit- } \\
\text { ral stenosis }\end{array}$ & 2 \\
\hline III & 53 & $\mathbf{F}$ & 27 & 44 & 63 & $\begin{array}{c}\text { Abnormal res- } \\
\text { ponse at } 350 \\
\mathrm{~kg} \cdot \mathrm{m} . / \mathrm{min} .\end{array}$ & 1 \\
\hline
\end{tabular}


Thus a patient who completes five minutes of exercise with normal ventilatory response at both 300 and $350 \mathrm{~kg}$. m. $/ \mathrm{min}$. levels is very unlikely to have critically tight mitral stenosis. On the other hand, we do not suggest that an abnormal ventilatory response to exercise necessarily indicates an immediate need for surgery. It will be seen in Fig. 1 that eight of the 20 clinical grade I patients had S.V.s above the upper limits of normal. Three of these eight cases, who had S.V.s of 32,33 , and $34 \mathrm{l} . / \mathrm{min}$., have since deteriorated clinically with a further rise in ventilatory cost of exercise. All three have now had valvotomies and in each case the valve was found to be critically tight. In our experience, a relatively symptomless patient with mitral stenosis who shows an abnormal standardized ventilation is likely to deteriorate later and require surgical treatment.

DURATION OF EXERCISE.-The number of patients in each clinical grade who completed five minutes of exercise is shown in Table III.

TABLE III

NO. OF PATIENTS COMPLETING FIVE MINUTES OF EXERCISE

\begin{tabular}{c|c|c}
\hline $\begin{array}{c}\text { Clinical } \\
\text { Grade }\end{array}$ & $\begin{array}{c}\text { No. of } \\
\text { Patients }\end{array}$ & $\begin{array}{c}\text { No. Completing } \\
\text { 5 min. Exercise }\end{array}$ \\
\hline II & 20 & $20(100 \%)$ \\
III & 18 & $15(83 \%)$ \\
IV & 57 & $32(57 \%)$ \\
\hline
\end{tabular}

We have found that failure to complete the five minutes of exercise is often a useful indication of physical disability. Whilst clearly the patient's personality must play some part, purely ventilatory factors sometimes appear to be largely

TABLE IV

PRE-OPERATIVE EXERCISE VENTILATION (E.V.) AND STANDARDIZED VENTILATION (S.V.) OF PATIENTS PERFORMING STEPPING TEST AT 300 KG. M./MIN. WORK LEVEL

\begin{tabular}{|c|c|c|c|c|c|c|}
\hline \multirow[b]{2}{*}{ Clinical grade ... } & \multicolumn{3}{|c|}{$\begin{array}{l}\text { A } \\
67 \text { Patients } \\
\text { Completing Exercise } \\
\text { for } 5 \text { min. }\end{array}$} & \multicolumn{3}{|c|}{$\begin{array}{c}\text { B } \\
\text { 38 Patients Failing to } \\
\text { Complete Exercise } \\
\text { for } 5 \text { min. }\end{array}$} \\
\hline & I & II & III & II & III & IV \\
\hline No. of patients & 20 & 15 & 32 & 3 & 25 & 10 \\
\hline $\begin{array}{l}\text { E.V. } \\
(1 . / \mathrm{min} .)\end{array}\left\{\begin{array}{l}\text { Mean } \\
\text { Range } \\
\text { S.D. }\end{array}\right.$ & $\begin{array}{c}26 \cdot 1 \\
19-34 \\
4 \cdot 6\end{array}$ & $\underset{7 \cdot 5}{23-45}$ & $\begin{array}{c}36 \\
24-47 \\
4.9\end{array}$ & $\begin{array}{c}27 \cdot 7 \\
20-36 \\
8\end{array}$ & $\begin{array}{c}33 \cdot 4 \\
25-46 \\
6.3\end{array}$ & $\begin{array}{c}36 \cdot 2 \\
22-44 \\
8 \cdot 1\end{array}$ \\
\hline $\begin{array}{l}\text { S.V. } \\
(1 . / \text { min. })\end{array}\left\{\begin{array}{l}\text { Mean } \\
\text { Range } \\
\text { S.D. }\end{array}\right.$ & $\begin{array}{c}27 \cdot 8 \\
19-34 \\
4.7\end{array}$ & $\begin{array}{c}34 \\
24.46 \\
7 \cdot 6\end{array}$ & $\begin{array}{c}40 \cdot 8 \\
27-59 \\
7 \cdot 4\end{array}$ & $\begin{array}{c}44 \\
41-46 \\
2 \cdot 6\end{array}$ & $\begin{array}{c}49 \\
32-67 \\
9 \cdot 3\end{array}$ & $\begin{array}{c}62 \cdot 3 \\
42-86 \\
13 \cdot 3\end{array}$ \\
\hline 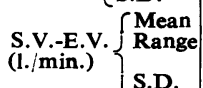 & $\begin{array}{l}1.7 \\
-1 \text { to } \\
+10 \\
2.2\end{array}$ & $\begin{array}{c}2.4 \\
-1 \text { to } \\
+9 \\
2.5\end{array}$ & $\begin{array}{l}4.8 \\
-2 \text { to } \\
+18\end{array}$ & $\begin{array}{l}16 \cdot 3 \\
5-25\end{array}$ & $\begin{array}{l}15 \cdot 4 \\
0-35\end{array}$ & $\begin{array}{l}26 \cdot 1 \\
12-51\end{array}$ \\
\hline $\begin{array}{c}\text { Exercise } \\
\text { time } \\
\text { (min.) }\end{array}\left\{\begin{array}{l}\text { Mean } \\
\text { Range }\end{array}\right.$ & 5 & $\stackrel{5}{-}$ & 5 & $\begin{array}{c}2 \cdot 9 \\
1 \cdot-4\end{array}$ & $\begin{array}{c}2 \cdot 6 \\
1 \frac{1}{2}-4\end{array}$ & $\begin{array}{l}13 \cdot 3 \\
2 \cdot 7 \\
1 \frac{1}{2}-4\end{array}$ \\
\hline
\end{tabular}

responsible for the premature cessation of exercise. These factors will be discussed in detail elsewhere.

Relationship of E.V. To S.V.-Since a steady ventilatory state is normally reached only in the fourth or fifth minute of exercise, patients who fail to complete the exercise will almost certainly have a higher S.V. than E.V. Thirtyfive of the 38 patients in this series who failed to complete the exercise had an S.V. exceeding their E.V. by five or more $1 . / \mathrm{min}$. (Table IVB).

When five minutes of exercise is completed, it would be expected from Hugh-Jones's work (1952) that the E.V. and S.V. should be equal. We have again confirmed that this is by no means always true in mitral patients (Table IVA).

In 21 of the 67 patients summarized in Table II who completed the exercise, the S.V. exceeded the E.V. by five or more $1 . / \mathrm{min}$., in one case by as much as $18 \mathrm{l} . / \mathrm{min}$. This discrepancy between the E.V. and S.V. was found to be both larger and more frequent the more disabled the group of patients. It was shown by two out of 20 clinical grade I, by three out of 15 grade II, and by 16 out of 32 grade III patients. The figures for grades I and II combined are significantly different from those of grade III $\left(\chi^{2}=10.0\right.$, $P<0.01$ ).

Fig. 2 illustrates graphically the mean ventilatory curve of the 32 clinical grade III patients who completed five minutes of exercise compared with the similar mean curve of the 20

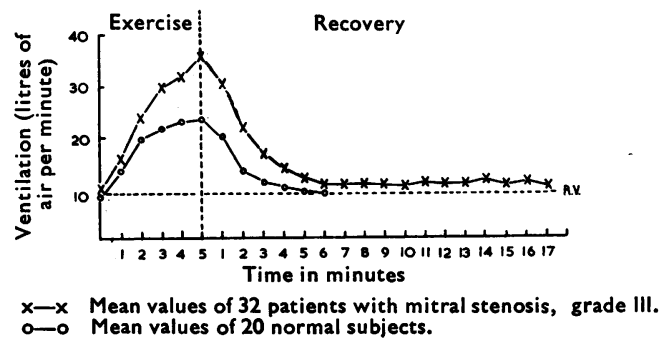

Fig. 2.-Mean ventilatory curves of 32 grade III mitral stenosis patients and of 20 normal subjects.

normal subjects. It will be seen that the ventilatory curve of the mitral patients has an abnormal contour with a rapid and continued rise throughout exercise and a greatly prolonged recovery phase.

RELATIONSHIP OF VENTILATORY COST OF Exercise to the Resting Pulmonary Vascular Pressures and Cardiac OUtPut.-In 40 patients the S.V. values have been compared with the resting pulmonary vascular pressures and resting cardiac output obtained during routine cardiac catheterization. There appears to be some 
relationship between the S.V. and the resting pulmonary capillary pressure $(r=0.401, \mathrm{P}<0.01)$ and between the S.V. and the mitral index (Wood, 1956) which is an approximate guide to mitral valve size $(r=0.439, \mathrm{P}<0.01)$.

On the other hand, there appears to be a somewhat closer correlation between the value for the S.V. and the pulmonary vascular resistance, best seen when the latter is plotted logarithmically (Fig. 3). The correlation coefficient between them is 0.506 , becoming $0.64 \quad(\mathrm{P}<0.01)$ when the logarithmic transformations of the figures for the

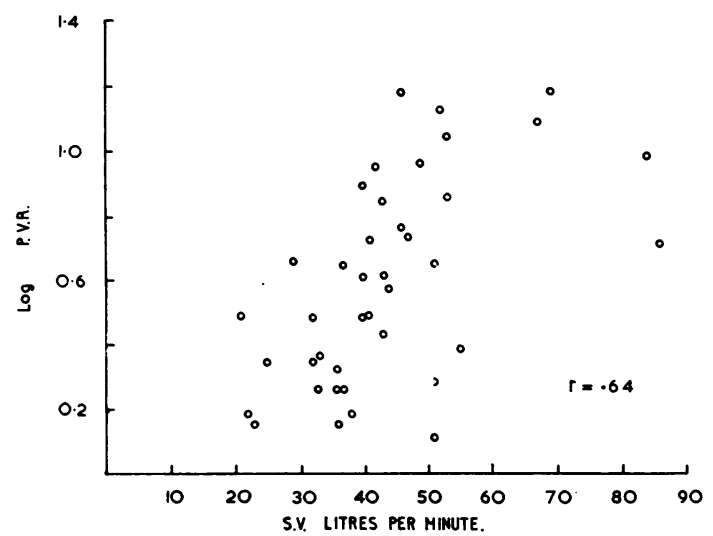

FIG. 3.-Standardized ventilation related to pulmonary vascular resistance (on a $\log$ scale) in $\mathbf{4 0}$ patients with mitral stenosis.

pulmonary vascular resistance are used. Since the higher the pulmonary vascular resistance the greater the braking effect on cardiac output, this finding is at least consistent with the view that the increased ventilatory requirements for exercise in these patients relate to an inadequate response of the cardiac output and hence an inadequate oxygen uptake during exercise.

\section{Post-OPERATIVE Findings}

Ventilatory tests have been repeated at three months, six months, and one year after valvotomy and then at yearly intervals. An independent clinical assessment of the patient's disability was made on each occasion before the ventilatory tests were done. One year after operation the results were classified on clinical grounds as " excellent," "good," "moderate," or " poor," according to the following criteria :

"Excellent" results were those in patients classed as clinical grade I or better, whatever their pre-operative grade had been.

"Good" results were those in patients classed as clinical grade II provided their clinical status had improved by at least one whole grade.

"Moderate" results were those in patients who appeared able to do more following operation but could not be regarded as having improved by a whole clinical grade.

"Poor" results were those in patients who showed no improvemeut or were worse.

COMPaRison OF Clinical and Ventilatory Findings ONe Year After Valvotomy.-The most logical indices for comparison with the post-operative clinical assessment are the absolute value for the post-operative S.V., together with the duration of exercise and the numerical relation of the E.V. and S.V. where five minutes of exercise is completed. For example, one would expect patients classed as an "excellent" result, i.e., clinical grade I or better, to have an S.V.

TABLE V

EXERCISE TEST RESULTS AND CLINICAL GRADES OF 63 PATIENTS BEFORE AND ONE YEAR AFTER MITRAL VALVOTOMY

\begin{tabular}{|c|c|c|c|c|c|c|c|c|c|c|c|c|c|c|c|c|}
\hline \multirow{3}{*}{$\begin{array}{l}\text { Post- } \\
\text { operative } \\
\text { Clinical } \\
\text { Assess- } \\
\text { ment }\end{array}$} & \multirow{3}{*}{$\begin{array}{l}\text { No. of } \\
\text { Patients }\end{array}$} & \multicolumn{6}{|c|}{ Pre-operative Findings } & \multicolumn{7}{|c|}{ Post-operative Findings } & \multirow{2}{*}{\multicolumn{2}{|c|}{$\begin{array}{c}\text { Difference } \\
\text { between } \\
\text { Pre- and } \\
\text { Post-operative } \\
\text { Values }\end{array}$}} \\
\hline & & \multicolumn{3}{|c|}{$\begin{array}{l}\text { Clinical } \\
\text { Grade }\end{array}$} & \multirow{2}{*}{$\begin{array}{c}\text { Mean } \\
\text { E.V. } \\
\text { (1. min.) }\end{array}$} & \multirow{2}{*}{$\begin{array}{c}\text { Mean } \\
\text { S.V. } \\
\text { (1./min.) }\end{array}$} & \multirow{2}{*}{$\begin{array}{c}\text { No. of } \\
\text { Patients } \\
\text { Completing } \\
\text { Exercise } \\
\text { for } 5 \text { min. }\end{array}$} & \multicolumn{4}{|c|}{ Clinical Grade } & \multirow[t]{2}{*}{$\begin{array}{l}\text { Mean } \\
\text { E.V. }\end{array}$} & \multirow[t]{2}{*}{$\begin{array}{l}\text { Mean } \\
\text { S.V. }\end{array}$} & \multirow{2}{*}{\begin{tabular}{|c|} 
No. of \\
Patients \\
Completing \\
Exercise \\
for 5 min.
\end{tabular}} & & \\
\hline & & II & III & IV & & & & I & II & III & IV & & & & E.V. & S.V. \\
\hline $\begin{array}{l}\text { Excellent } \\
\text { results }\end{array}$ & 38 & 10 & 24 & 4 & $\begin{array}{c}34 \cdot 4 \\
(24-44)\end{array}$ & $\begin{array}{c}43 \\
(24-86)\end{array}$ & 24 & 38 & - & - & - & $\begin{array}{l}25 \cdot 1 \\
(19-44)\end{array}$ & $\begin{array}{c}28.4 \\
(19-44)\end{array}$ & 37 & $\begin{array}{c}-9 \cdot 3 \\
(-19 \text { to }\end{array}$ & $\begin{array}{l}-14 \cdot 6 \\
(-45 \text { to }\end{array}$ \\
\hline $\begin{array}{l}\text { Good } \\
\text { results }\end{array}$ & 9 & - & 7 & 2 & $\begin{array}{c}\text { S.D. } 6 \cdot 2 \\
37 \cdot 2 \\
(30-44) \\
\text { S.D. } 5 \cdot 6\end{array}$ & $\begin{array}{c}\text { S.D. } 12 \cdot 6 \\
55 \cdot 3 \\
(30-82) \\
\text { S.D. 15.8 }\end{array}$ & 3 & - & 9 & - & - & $\begin{array}{c}\text { S.D. } 0 \cdot 2 \\
29 \cdot 4 \\
(23-36) \\
\text { S.D. } 4 \cdot 3\end{array}$ & $\begin{array}{c}\text { S.D. } 5 \cdot 5 \\
\text { 33.2 } \\
(23-41) \\
\text { S.D. } 7\end{array}$ & 8 & $\begin{array}{c}+14) \\
-7 \cdot 8 \\
(-20 \text { to } \\
+5)\end{array}$ & $\begin{array}{c}+52 \\
-22 \cdot 1 \\
(-52 \text { to } \\
-7)\end{array}$ \\
\hline $\begin{array}{l}\text { Moderate } \\
\text { results }\end{array}$ & 6 & 1 & 3 & 2 & $\begin{array}{c}36 \cdot 1 \\
(23-42) \\
\text { S.D. } 7 \cdot 3\end{array}$ & $\begin{array}{c}49.7 \\
(24-59) \\
\text { S.D. } 13\end{array}$ & 3 & - & - & 6 & - & $\begin{array}{c}34.8 \\
(23-53) \\
\text { S.D. } 11 \cdot 1\end{array}$ & $\begin{array}{c}46 \cdot 3 \\
(23-89) \\
\text { S.D. } 23\end{array}$ & 3 & $\begin{array}{c}-1 \cdot 3 \\
(-12 \text { to } \\
+12)\end{array}$ & $\begin{array}{c}-3.4 \\
(-19 \text { to } \\
+34)\end{array}$ \\
\hline $\begin{array}{l}\text { Poor } \\
\text { results }\end{array}$ & 10 & 3 & 6 & 1 & $\begin{array}{l}3.7 \cdot 3 \\
(21-45) \\
\text { S.D. 8.2 }\end{array}$ & $\begin{array}{c}39 \cdot 5 \\
(27-45) \\
\text { S.D. } 5 \cdot 7\end{array}$ & 7 & - & - & - & 10 & $\begin{array}{c}34 \cdot 7 \\
(23-49) \\
\text { S.D. } 9 \cdot 9\end{array}$ & $\begin{array}{c}42 \cdot 3 \\
(30-51) \\
\text { S.D. } 7 \cdot 3\end{array}$ & 5 & $\begin{array}{c}+12 \\
(-14 \text { to } \\
+18)\end{array}$ & $\begin{array}{c}+2 \cdot 8 \\
(-11 \text { to } \\
+16)\end{array}$ \\
\hline Total & 63 & 14 & 40 & 9 & & & 37 & 38 & 9 & 6 & 10 & & & 53 & & \\
\hline
\end{tabular}


within the range of normal or clinical grade I subjects and to complete five minutes of exercise with a numerically equal E.V. and S.V.

The clinical grade, exercise time, and values for the E.V. and S.V. before operation of 63 of the original 85 patients who had adequate corresponding data one year after operation are summarized in Table V. Thirty-eight of the 63 patients $(60.2 \%)$ were classified clinically as " excellent" results, nine were classed as "good" results $(14.3 \%)$, six as "moderate" results $(9.4 \%)$, and 10 as "poor" results $(16.1 \%)$. Although there are some exceptions, there is in general a reasonably close correspondence between the clinical assessment of operative result and any change in the ventilatory findings.

Excellent Results.-The mean S.V. of this group was $43 \mathrm{l}$./ $\mathrm{min}$. (S.D. 12.6) before operation and $28.41 . / \mathrm{min}$. (S.D. 5.7) one year after. Fourteen of the 38 patients failed to complete five minutes of exercise before operation; only one failed to do so after. The S.V. exceeded the E.V. by five or more $1 . / \mathrm{min}$. in nine of the 24 patients who completed five minutes of exercise before operation. This discrepancy occurred in only three out of 37 patients after operation. This is due to the ventilatory curve assuming a more normal and symmetrical contour after operation with an approximately steady state in the last minutes of exercise and a normal recovery phase (Fig. 4).

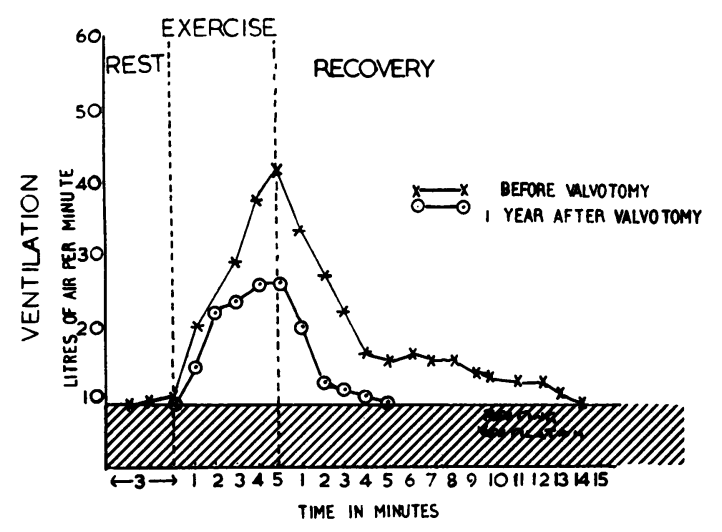

FIG. 4.-Ventilatory curve during and after exercise in a patient (Case 27) with mitral stenosis before and after valvotomy. Pre-operative values for E.V. and S.V. were $421 . / \mathrm{min}$. and 511 . $/ \mathrm{min}$., and post-operative values were $271 . / \mathrm{min}$. and $281 . / \mathrm{min}$.

Six patients still had S.V.s of $341 . / \mathrm{min}$. or more, i.e., above the upper limit for grade I patients. Two of these patients (Cases 81 and 97) seemed clinically to be unquestionably "excellent" results as defined above and have so far maintained this clinical status up to two years following operation. The remaining four patients have all since relapsed clinically.

Good Results.-The patients in this group as a whole were more disabled before operation than those in the "excellent" group, and their mean S.V. shows a larger post-operative fall but not to the same low level as that of the "excellent" results.

Moderate Results.-Not much can be said about this small group except that they appeared slightly better clinically. After operation there was a fall in the S.V. of five of the six patients. Nevertheless, four patients still had a postoperative S.V. of $40 \mathrm{1}$./ $\mathrm{min}$. or more.

Poor Results.-The mean post-operative S.V. of this group is substantially the same as the pre-operative value. With one exception the individual values showed little change.

Serial Ventilatory Assessments over Four Post-OPERATIVE Years.-There are satisfactory serial data over four or more post-operative years for 17 patients classed as "excellent" results and four as "good" results one year after operation. The data for these 21 patients are presented in Table VI.

The mean values of ventilatory cost of exercise show an initial sharp drop at three months, followed by a further gradual fall up to two years to reach a mean value of $28.81 . / \mathrm{min}$. After three years, however, the mean value has risen to 32.7 $1 . / \mathrm{min}$., and after four years to $36.1 \mathrm{1} / \mathrm{min}$. though these last mean values are loaded by those patients whose valves had re-stenosed.

The S.V. of one patient was lowest at three months after operation, of three at six months, of seven at one year, of eight at two years, and in the other two at three years after operation.

Prognostic Value of Standardized VentilaTION AFTER OPERATION.-Examination of the earlier post-operative tests in this group of clinically comparable operative results suggests that the most useful forewarning of later clinical relapse may be given by the S.V. value one year after valvotomy. At this time, when the clinical status of the group as a whole was more or less uniform, the 21 patients can be divided into three groups according to the individual S.V.s.

Six patients had S.V.s of $241 . / \mathrm{min}$. or less. At the end of four years, five of these patients still have an S.V. of less than $31 \mathrm{1} . / \mathrm{min}$. and are all still regarded clinically as "excellent" results. 
TABLE VI

PRE-OPERATIVE S.V. DATA OF 21 PATIENTS AND SERIAL S.V. DATA FOR FOUR YEARS AFTER MITRAL VALVOTOMY

\begin{tabular}{|c|c|c|c|c|c|c|c|c|c|c|}
\hline \multirow{2}{*}{$\begin{array}{l}\text { Case } \\
\text { No. }\end{array}$} & \multirow{2}{*}{$\begin{array}{l}\text { Pre-operative } \\
\text { Clinical } \\
\text { Grade }\end{array}$} & \multirow{2}{*}{$\begin{array}{l}\text { Pre-operative } \\
\text { S.V. } \\
\text { (1./min.) }\end{array}$} & \multirow{2}{*}{$\begin{array}{c}\text { Post-operative } \\
\text { Clinical } \\
\text { Grade at } \\
\text { One Year }\end{array}$} & \multicolumn{6}{|c|}{ Post-operative S.V. (1./min.) } & \multirow{2}{*}{$\begin{array}{c}\text { Clinical } \\
\text { Grade at } \\
\text { Four } \\
\text { Years }\end{array}$} \\
\hline & & & & $\begin{array}{l}\text { Three } \\
\text { Months }\end{array}$ & $\begin{array}{c}\text { Six } \\
\text { Months }\end{array}$ & $\begin{array}{l}\text { One } \\
\text { Year }\end{array}$ & $\begin{array}{l}\text { Two } \\
\text { Years }\end{array}$ & $\begin{array}{l}\text { Three } \\
\text { Years }\end{array}$ & $\begin{array}{l}\text { Four } \\
\text { Years }\end{array}$ & \\
\hline $\begin{array}{l}25 \\
21 \\
27 \\
46 \\
53 \\
64 \\
28 \\
16 \\
11 \\
41 \\
6 \\
30 \\
17 \\
59 \\
14 \\
34 \\
50 \\
10 \\
63 \\
18 \\
26\end{array}$ & $\begin{array}{l}\text { III } \\
\text { III } \\
\text { III } \\
\text { III } \\
\text { III } \\
\text { III } \\
\text { III } \\
\text { III } \\
\text { IV } \\
\text { IV } \\
\text { III } \\
\text { III } \\
\text { III } \\
\text { III } \\
\text { IIV } \\
\text { III } \\
\text { III } \\
\text { III }\end{array}$ & $\begin{array}{l}41 \\
43 \\
51 \\
46 \\
27 \\
35 \\
37 \\
67 \\
53 \\
38 \\
52 \\
52 \\
38 \\
36 \\
54 \\
43 \\
46 \\
59 \\
58 \\
63 \\
62\end{array}$ & $\begin{array}{l}\text { I } \\
\text { I } \\
\text { I } \\
\text { I } \\
\text { I } \\
\text { I } \\
\text { I } \\
\text { I } \\
\text { I } \\
\text { I } \\
\text { I } \\
\text { I } \\
\text { I } \\
\text { I } \\
\text { I } \\
\text { II } \\
\text { II } \\
\text { II } \\
\text { II }\end{array}$ & $\begin{array}{l}31 \\
35 \\
30 \\
27 \\
21 \\
27 \\
25 \\
41 \\
46 \\
27 \\
41 \\
41 \\
37 \\
33 \\
38 \\
44 \\
31 \\
59 \\
43 \\
43 \\
41\end{array}$ & $\begin{array}{l}20 \\
35 \\
30 \\
30 \\
21 \\
29 \\
31 \\
34 \\
31 \\
29 \\
36 \\
36 \\
35 \\
36 \\
27 \\
40 \\
26 \\
43 \\
41 \\
34 \\
46\end{array}$ & $\begin{array}{l}19 \\
22 \\
23 \\
24 \\
24 \\
24 \\
25 \\
26 \\
29 \\
29 \\
30 \\
31 \\
32 \\
32 \\
34 \\
34 \\
35 \\
27 \\
38 \\
41 \\
41\end{array}$ & $\begin{array}{l}20 \\
24 \\
24 \\
29 \\
26 \\
28 \\
25 \\
24 \\
21 \\
35 \\
24 \\
27 \\
30 \\
31 \\
31 \\
29 \\
44 \\
28 \\
36 \\
32 \\
37\end{array}$ & $\begin{array}{l}21 \\
25 \\
25 \\
31 \\
26 \\
32 \\
25 \\
23 \\
23 \\
74 \\
26 \\
34 \\
23 \\
31 \\
36 \\
33 \\
45 \\
29 \\
43 \\
40\end{array}$ & $\begin{array}{l}20 \\
26 \\
26 \\
32 \\
25 \\
29 \\
34 \\
30 \\
23 \\
55 \\
36 \\
33 \\
35 \\
35 \\
56 \\
34 \\
45 \\
49 \\
55 \\
34 \\
47\end{array}$ & $\begin{array}{r}\text { I } \\
\text { I } \\
\text { I } \\
\text { II } \\
\text { I } \\
\text { I } \\
\text { II } \\
\text { III } \\
\text { II } \\
\text { II } \\
\text { III } \\
\text { III } \\
\text { III } \\
\text { III } \\
\text { III }\end{array}$ \\
\hline $\begin{array}{l}\text { Total } \\
\text { Mean } \\
\text { Range } \\
\text { S.D. }\end{array}$ & & $\begin{array}{r}1,001 \\
47.7 \\
27-67 \\
10.7\end{array}$ & & $\begin{array}{r}761 \\
36 \cdot 2 \\
21-59 \\
8 \cdot 8\end{array}$ & $\begin{array}{c}690 \\
32.9 \\
20-46 \\
6.6\end{array}$ & $\begin{array}{r}620 \\
29 \cdot 5 \\
19.41 \\
6.2\end{array}$ & $\begin{array}{r}605 \\
28.8 \\
20-44 \\
5.7\end{array}$ & $\begin{array}{c}687 \\
32.7 \\
21-74 \\
11.9\end{array}$ & $\begin{array}{c}759 \\
36.1 \\
20-56 \\
10.9\end{array}$ & \\
\hline
\end{tabular}

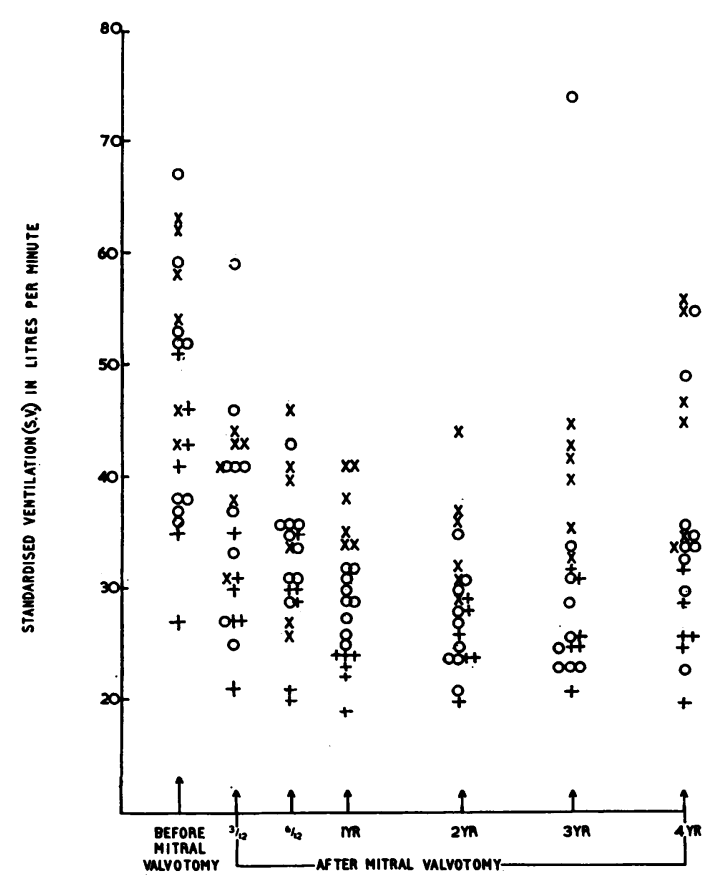

Fig. 5.-Changes in standardized ventilation up to four years after mitral valvotomy. The symbols group the patients according to the standardized ventilation rate one year after valvotomy.
The remaining patient's S.V. has risen to 32 $1 . / \mathrm{min}$. and she is now clinically assessed as grade II.

Six patients had S.V.s of $341 . / \mathrm{min}$. or more (range 34 to $411 . / \mathrm{min}$ ) one year after operation. At the fourth year assessment, four of these patients have S.V.s of $451 . / \mathrm{min}$. or more (range 45 to $561 . / \mathrm{min}$.). All four have relapsed clinically to their pre-operative grade, three due to re-stenosis and one with mitral incompetence. The other two have a four-year S.V. of 34 and $35 \mathrm{l} . / \mathrm{min}$. respectively and are both now assessed as clinical grade II, but on the whole remain satisfactory operative results.

The intermediate group of nine patients with S.V.s ranging from 25 to $32 \mathrm{l} / \mathrm{min}$. have experienced varying fortunes in the ensuing three years. At the end of four years two are in the high S.V. group with values of 49 and $551 . / \mathrm{min}$. respectively. In one of these, the mitral valve has frankly re-stenosed; the second had had a recent pulmonary embolus at the time of her test and her present clinical status is uncertain.

Thus, from the data presented it would appear that with an S.V. of $24 \mathrm{l} . / \mathrm{min}$. or less at one year, the operative improvement is likely to be maintained. On the other hand, an S.V. at this time of $34 \mathrm{l} . / \mathrm{min}$. or more may well foreshadow complete clinical relapse.

Two years after operation the S.V. of some patients has fallen further, while that of others 
has risen. If the 21 S.V.s at this time are arbitrarily divided into three equal groups, these three groups almost maintain their relative positions at the end of four years although the mean value of the S.V. has risen.

In our experience, the S.V. has proved a sensitive index of re-stenosis, the ventilatory cost of exercise usually beginning to rise before the reappearance of symptoms. Case 14 is a typical example of an excellent operative result with subsequent re-stenosis. She was aged 29 with a pre-operative history of increasing exertional dyspnoea for 10 years. For 12 months before operation she had been virtually completely incapacitated and was assessed as a late clinical grade III disability. At operation in 1953 the size of the mitral valve was estimated to be less than $1 \mathrm{~cm}^{2}$ and the surgeon considered the valve was adequately split. After operation there was a dramatic clinical improvement with a corresponding fall in her S.V. She was not only able to do all her housework and shopping but also obtain secretarial employment and lead an active social life in addition. At the end of the third year after operation her S.V. began to rise, and during the fourth year symptoms reappeared, and four years after operation her relapse was complete. It is of interest that the S.V. began to rise before she complained of returning symptoms. A second valvotomy was performed in 1957 and the valve was again estimated at less than $1 \mathrm{~cm} .^{2}$ Unfortunately she failed to survive the operation. Fig. 6 shows the values for the S.V. at two pre-operative tests in 1953 and the

SUCCESSFUL MITRAL VALVOTOMY WITH SUBSEQUENT RESTENOSIS.

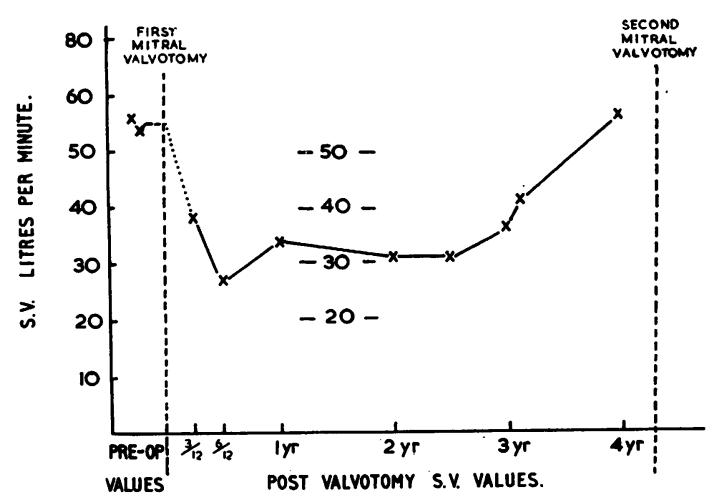

FIG. 6. - Standardized ventilation at intervals after mitral valvotomy in a patient whose valve re-stenosed. serial values obtained during the four years up to her second operation.

The S.V.s of other patients with re-stenosis, proved at operation, necropsy, or by cardiac catheterization, have behaved in a similar way.

\section{Discussion}

Measurement of the ventilatory cost of exercise appears to provide a useful and simple objective addition to the clinical assessment of disability both before and after operation. It is possible that modifications of the test may further enhance its clinical usefulness.

Dyspnoea in mitral stenosis is at present largely attributed to the increased work of breathing from a reduced lung compliance (Wood, 1956), although no direct correlation has yet been shown between measurements of lung distensibility and the clinical severity of the dyspnoea (Hayward and Knott, 1955). We think that perhaps insufficient attention has been paid to the hyperventilation on exercise in considering the pathogenesis of symptoms in these patients. A reduced lung compliance must clearly contribute to the dyspnoea, more especially since many disabled mitral patients, despite the increased work for each breath, achieve during relatively mild exertion a minute volume of ventilation (E.V.) which normal subjects would require only for much more strenuous activities. Insufficient attention has, moreover, been paid to the asymmetrical contour of the ventilatory curve which is so common in disabled mitral patients (Fig. 2). Even when five minutes of exercise is completed, the total ventilatory cost of the exercise may not be appreciated from the E.V. alone due to the prolonged recovery phase. On the other hand, the S.V., which takes the recovery period into account, is not only a better index of the total ventilatory response but we find it correlated more closely with clinical disability. Other symptoms than dyspnoea also occur in mitral stenosis, such as exhaustion, fatigued muscles, and aching limbs. Such symptoms may be due to a large oxygen debt, the necessary repayment of which during recovery could lead to the discrepancy between the S.V. and the E.V.

The relationship between the disturbed haemodynamics and the ventilatory changes in mitral stenosis is not yet fully understood. A number of workers have suggested that the hyperventilation on effort is due to an inadequate response of the cardiac output so that a large 
oxygen debt accumulates during exercise (Stock and Kennedy, 1953 ; Cotes, 1955 ; Holling and Venner, 1956 ; Govaerts, Lequime, and Denolin, 1954; Wyndham and Ward, 1957). Donald, Bishop, Wade, and Wormald (1957), however, in their extensive studies of mitral stenosis failed to demonstrate a simple inverse relation between ventilation and cardiac output. After successful valvotomy, they found that many of their " excellent" results had a better exercising cardiac output, but that the exercising cardiac output of some patients remained abnormally low although the E.V. had returned to normal. We are unable, however, to accept their suggestion that the minimal arterial oxygen unsaturation on exercise which they found in their patients is responsible for the hyperventilation. Jongbloed, van Nieuwenhuizen, and van Goor (1957), by continuous registration of oxygen uptake during exercise and recovery, confirmed that an abnormally large oxygen debt is accumulated during effort by mitral patients and is repaid during the prolonged recovery phase. It is reasonable to suppose that the high S.V. values we have found are a reflection of this large oxygen debt. This suggestion is supported by Cotes's finding (1955) that there is an abnormal increase in blood lactic acid on exercise in mitral stenosis. He found this increase to relate more closely to the S.V. than to the E.V. and also to the difference between the S.V. and E.V. While other factors may be involved, an increased blood lactic acid level due to anaerobic muscular activity is probably important in stimulating the respiratory centre.

If a large oxygen debt is in fact responsible for the excess ventilation, the maximum oxygen uptake which the subject can achieve must clearly be a critical factor in determining hyperventilation. It is probable that in mitral stenosis the limiting factor in oxygen uptake is usually a restricted cardiac output rather than ventilation or diffusion. As soon as the oxygen demands of exercise reach or pass the maximum oxygen uptake, a vicious circle becomes established which, as McIlroy (1959) points out, will be aggravated by a reduced lung compliance involving a high oxygen cost for breathing, for as ventilation increases with the accumulating oxygen debt an increasing proportion of the limited oxygen uptake must be diverted to the respiratory muscles. Thus, the rising ventilation can now only accelerate the rate at which the oxygen debt accumulates. If, after valvotomy, an improved lung compliance sufficiently reduces the oxygen cost of breathing to lower the total oxygen requirements for the same exercise significantly, the finding of Donald and others that the E.V. may fall to normal without a proportionate increase in the exercising cardiac output can readily be understood.

\section{SUMMARY}

The ventilatory cost of exercise has been measured in 20 normal subjects and 105 patients with mitral stenosis. Eighty-five patients later underwent mitral valvotomy, and serial clinical and ventilatory data before and after operation are presented.

Two main indices are derived from the exercise test employed. "Exercise ventilation" (E.V.) is arbitrarily defined as the ventilation in litres during the last minute of exercise, whether the subject completes the five minutes or not. "Standardized ventilation" (S.V.) is an index of. the ventilatory cost of exercise which takes the recovery period into account and thus is virtually independent of the exercise time, provided that two minutes of exercise are completed. In mitral stenosis the S.V. often exceeds the E.V. and this discrepancy occurs with increasing frequency the more disabled the patient. For this and other various reasons the S.V. is the more useful index in mitral stenosis.

In 20 clinical grade I patients with mitral stenosis, the mean standardized ventilation was 27.41 . $/ \mathrm{min}$. (S.D. 4.7), in 18 grade II patients 35.4 $1 . /$ min. (S.D. 8.1), in 57 grade III patients 44.4 1./min (S.D. 9.2), and in 10 grade IV patients $62.21 . / \mathrm{min}$. (S.D. 14). Thus, increasing disability in mitral stenosis is associated with an increasing S.V.

The completion of five minutes of exercise with a normal ventilatory response at both 300 and $350 \mathrm{~kg}$. $\mathrm{m} . / \mathrm{min}$. virtually excludes the presence of tight mitral stenosis. An abnormal response may not be an indication for operation but commonly foreshadows future deterioration.

One year after valvotomy, a group of 63 patients showed a general correspondence between the clinical assessment and the change in the S.V. In the best results, the S.V. falls progressively during the first one or two years after operation. In addition to the fall in the total ventilatory cost of exercise, the ventilatory curve assumes a more normal contour so that the E.V. and the S.V. become numerically equal.

The test has proved a sensitive index of re-stenosis, a rise in the S.V. often preceding the reappearance of symptoms. In patients of comparable clinical status, the S.V. one year after valvotomy is often of prognostic value. 
Possible causes of the hyperventilation and its relationship to the symptoms in mitral stenosis are discussed.

We would like to express our indebtedness to Dr. G. E. King for his help in compiling the data. Acknowledgments are due to Mr. G. E. Crowe and Mr. J. M. Sanderson, who operated on these cases and for their help in providing data on the size of the mitral valve at operation. We should also like to acknowledge the valuable technical assistance of $\mathrm{Mr}$. J. Booth and Mr. R. Thompson, of the Respiratory Physiology Department, who carried out the ventilatory tests. We are also indebted to Mr. A. H. Iliffe for statistical help and advice and to Mrs. O. Adams and Mrs. M. Dewsnap for secretarial assistance.

\section{REFERENCES}

Baker, C., Brock, R. C., Campbell, M., and Wood, P. (1952). Brit. med. J., 1, 1043.

Cotes, J. E. (1955). Clin. Sci., 14, 317.

Donald, K. W., Bishop, J. M., Wade, O. L., and Wormald, P. N. (1957). Ibid., 16, 325.

Gilson, J. C., and Hugh-Jones, P. (1949). Ibid., 7, 185.

Govaerts, J., Lequime, J., and Denolin, H. (1954). Proc. 2nd Congress int. Soc. Angiology, Lisbon, 1953, p. 68.

Hayward, G. W., and Knott, J. M. S. (1955). Brit. Heart J., 17, 303

Holling, H. E., and Venner, A. (1956). Ibid., 18, 103.

Hugh-Jones, P. (1952). Brit. med. J., 1, 65.

Jongbloed, J., Nieuwenhuizen, C. L. C. van, and Goor, H. van (1957). Circulation, 15, 54.

Kennedy, M. C. S. (1953). Thorax, 8, 73.

McIlroy, M. B. (1959). Progr. cardiovascular Dis., 1, 284.

Stock, J. P. P., and Kennedy, M. C. S. (1953). Lancet, 2, 65.

Wood, P. (1956). Diseases of the Heart and Circulation. Eyre \& Spottiswoode, London.

Wyndham, C. H., and Ward, J. S. (1957). Circulation, 16, 384. 